\title{
Simultaneous Saccharification and Fermentation of Hydrothermal Pretreated Lignocellulosic Biomass: Evaluation of Process Performance Under Multiple Stress Conditions
}

\author{
Maikon Kelbert $^{1}$ • Aloia Romaní ${ }^{2}$ - Eduardo Coelho ${ }^{2} \cdot$ Francisco B. Pereira $^{2}$. \\ José A. Teixeira ${ }^{2} \cdot$ Lucília Domingues $^{2}$
}

Published online: 14 March 2016

(C) Springer Science+Business Media New York 2016

\begin{abstract}
Industrial lignocellulosic bioethanol processes are exposed to different environmental stresses (such as inhibitor compounds, high temperature, and high solid loadings). In this study, a systematic approach was followed where the liquid and solid fractions were mixed to evaluate the influence of varied solid loadings, and different percentages of liquor were used as liquid fraction to determine inhibitor effect. Ethanol production by simultaneous saccharification and fermentation (SSF) of hydrothermally pretreated Eucalyptus globulus wood (EGW) was studied under combined diverse stress operating conditions $\left(30-38^{\circ} \mathrm{C}, 60-80 \mathrm{~g}\right.$ of liquor from hydrothermal treatment or autohydrolysis (containing inhibitor compounds) $/ 100 \mathrm{~g}$ of liquid and liquid to solid ratio between 4 and $6.4 \mathrm{~g}$ liquid in SSF/g unwashed pretreated EGW) using an industrial Saccharomyces cerevisiae strain supplemented with low-cost byproducts derived from agro-food industry. Evaluation of these variables revealed that the combination of temperature and higher solid loadings was the most significant variable affecting final ethanol concentration and cellulose to ethanol conversion, whereas solid and autohydrolysis liquor loadings had the most significant impact on ethanol productivity. After optimization, an ethanol concentration of
\end{abstract}

Maikon Kelbert and Aloia Romaní contributed equally to this work.

Electronic supplementary material The online version of this article (doi:10.1007/s12155-016-9722-6) contains supplementary material, which is available to authorized users.

Lucília Domingues

luciliad@deb.uminho.pt

1 Chemical Engineering Department, Federal University of Santa Catarina, Florianopolis, SC, Brazil

2 CEB - Centre of Biological Engineering, University of Minho, Campus de Gualtar, 4710-057 Braga, Portugal
$54 \mathrm{~g} / \mathrm{L}$ (corresponding to $85 \%$ of conversion and $0.51 \mathrm{~g} / \mathrm{Lh}$ of productivity at $96 \mathrm{~h}$ ) was obtained at $37^{\circ} \mathrm{C}$ using $60 \%$ of autohydrolysis liquor and $16 \%$ solid loading (liquid to solid ratio of $6.4 \mathrm{~g} / \mathrm{g}$ ). The selection of a suitable strain along with nutritional supplementation enabled to produce noticeable ethanol titers in quite restrictive SSF operating conditions, which can reduce operating cost and boost the economic feasibility of lignocellulose-to-ethanol processes.

Keywords Inhibitor compounds $\cdot$ High temperature $\cdot$ High solid loading $\cdot$ Fermentation lignocellulosic biomass . Industrial strain $\cdot$ Hydrothermal treatment

\section{Introduction}

Nowadays, the use of renewable biomass to supply the increasing energetic needs and to partially replace fossil fuels is recognized as a suitable alternative to attain a sustainable growth based on a bioeconomy. Liquid fuel (as bioethanol) from lignocellulosic biomass is a promising solution since this raw material is renewable, widespread, and with a huge potential for the manufacture of products, without competing with food crops [1]. In order to achieve a cost-effective lignocellulosic bioethanol production process, industrial lignocellulosic fermentations depend on overcoming specific challenges that differ from conventional food fermentations [2]. These limiting conditions are related with the stages involved in the lignocellulosic process to produce ethanol.

Firstly, a pretreatment is necessary to break down the recalcitrant structure of lignocellulosic feedstock. Hydrothermal treatment, as autohydrolysis or liquid hot water, uses water as the only reaction medium and is considered an environmentally friendly pretreatment that improves enzymatic saccharification of lignocellulosic biomass and solubilizes the 
hemicellulosic fraction into oligosaccharides [3, 4]. Nevertheless, the autohydrolysis liquor (liquid phase after pretreatment) from hydrothermal processing also comprises sugar- and lignin-derived compounds (furans, weak acids, and phenolic compounds), considered inhibitors of enzymes and microorganisms used on saccharification and fermentation processes, respectively $[5,6]$.

Secondly, the whole slurry (liquor and pretreated biomass altogether) can be submitted to simultaneous enzymatic saccharification and fermentation (SSF) process. The saccharification and fermentation carried out in one stage presents more advantages than in separate steps, such as the risk of contamination and sugar inhibition effect are lower and the use of one reactor reduces operational cost [7]. In SSF process, thermotolerance is one of the most desired features of the fermentative microorganism, as high temperature $\left(50^{\circ} \mathrm{C}\right)$ is required for efficient enzymatic saccharification of cellulose to glucose, being the optimal operating temperature for Saccharomyces cerevisiae (main yeast used in ethanol fermentation) in the range of $25-30{ }^{\circ} \mathrm{C}$ [8]. In addition, the use of hightemperature in industrial fermentation processes can also lead to energy saving by (i) the reduction of cooling costs (mainly in tropical countries where the temperature varies between $30-40{ }^{\circ} \mathrm{C}$ throughout the year), (ii) reducing the viscosity leading to lower energy requirements for the homogenization of the fermentation medium, and (iii) facilitating ethanol recovery $[2,9,10]$.

Finally, a distillation of the SSF medium, for ethanol purification, is required as the last stage of the process. An industrial process that operates at high solid loading leads to a final ethanol concentration higher than moderate-low loadings, reducing distillation cost and water consumption [11]. For this purpose, ethanol concentration should be $>4 \%(w / w)$ which corresponds to a lignocellulosic biomass loading of $>20 \%$ $(w / w)$ for saccharification and fermentation [12]. Nevertheless, the high solid loadings hamper substrate mixing and consequently lead to poor mass transfer.

Together, the combination of these process challenges (inhibitor compounds, high temperature, and solid loadings) can lead to synergistic effects on enzyme and yeast with considerable impact on overall process performance. These synergistic effects could have a higher negative effect than a single factor on ethanol production being a necessary robust microorganism with a stress-tolerant ethanologenic background, which could make the difference to attain feasibility of lignocellulosic bioethanol process [13, 14].

In recent works, S. cerevisiae industrial strain PE-2, isolated from Brazilian fuel ethanol industry, has shown noteworthy fermentation efficiency and stress tolerance during industrial fermentation [15-18], showing high ethanol tolerance for very high gravity fermentation [19, 20], inhibitor resistance [16], and high cell viability at temperatures above $35{ }^{\circ} \mathrm{C}$ [21]. Moreover, optimized nutritional fermentation media can minimize the toxic effects of inhibitor compounds [22]. The previous work improved the slurry fermentation yield by nutritional supplementation using agro-industrial byproducts (corn steep liquor, cheese whey, and yeast extract supplemented with urea and $\mathrm{K}_{2} \mathrm{O}_{5} \mathrm{~S}_{2}$ ), increasing 2.4 and 7.4-fold ethanol production on separate and simultaneous saccharification and fermentation, respectively [23].

This work aims to investigate and optimize lignocellulosic simultaneous saccharification and fermentation under limiting process conditions (high temperature, inhibitor compounds, and high solid loadings) following the experimental procedure scheme proposed in Fig. 1. For that, the whole slurry from hydrothermal treatment of Eucalyptus globulus wood (EGW) was used at different proportions for addressing the solid loading and inhibitor effect. Autohydrolysis liquor (AL) from hydrothermal pretreatment (containing inhibitor compounds) at different percentages (60-80 $\mathrm{g}$ of AL/100 $\mathrm{g}$ of liquid in SSF) was mixed with unwashed and not dried pretreated EGW at different liquid/solid ratios (4-6.4 g of liquid in SSF (containing different percentage of $\mathrm{AL}$ ) $/ \mathrm{g}$ of pretreated $\mathrm{EGW}$ ) under temperatures in the range $30-38{ }^{\circ} \mathrm{C}$ using an industrial robust S. cerevisiae strain (PE2) and supplemented with optimized low-cost agro-industrial byproducts in a simultaneous saccharification and fermentation process.

\section{Materials and Methods}

\section{Raw Material}

EGW was collected in a local paper and pulp factory, milled to pass an 8-mm screen, homogenized and stored in a dark and dry place until use. EGW was assayed for extractives (NREL/TP-510-42618), ashes (NREL/TP-510-42622), and structural carbohydrate and lignin (NRL/TP-510-42618). The composition of raw material (expressed in $\mathrm{g} / 100 \mathrm{~g}$ EGW oven-dry basis) was previously analyzed by Pereira et al. [16] and listed in Table 1.

\section{Autohydrolysis Pretreatment of EGW}

The whole slurry (constituted by autohydrolysis liquor and pretreated EGW solid) used in this study was obtained from hydrothermal pretreatment of EGW (Fig. 1). For that, $800 \mathrm{~g}$ of water was mixed with $100 \mathrm{~g}$ of wood (corresponding to initial solid loading of $12.5 \% \mathrm{w} / \mathrm{w}$ ) in a stainless pressurized reactor at maximal temperature $\left(\mathrm{T}_{\max }\right)$ of $210{ }^{\circ} \mathrm{C}$ under nonisothermal conditions [24]. The percent of solid loading after treatment was $8.65 \mathrm{~g}$ of pretreated $\mathrm{EGW}$ solid/100 $\mathrm{g}$ of AL. After treatment, pretreated EGW solid was separated from liquid phase (autohydrolysis liquor) by vacuum filtration and washed for characterization of chemical composition and solid yield (SY) determination. The glucan, xylan, and acetyl 
Fig. 1 Schematic representation of the experimental procedure followed in this work

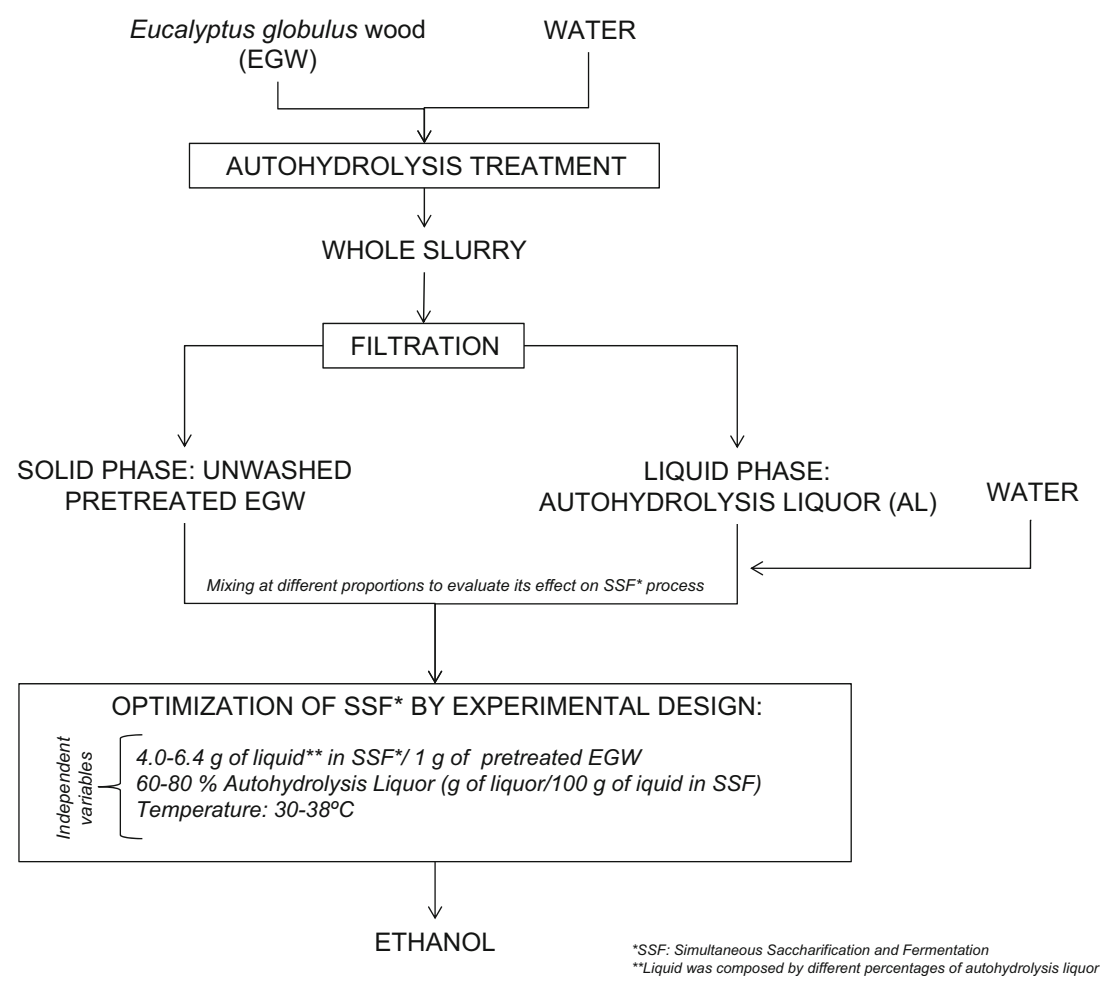

groups and Klason lignin content of solid fraction were quantified following the procedures described above. One aliquot of liquid phase or autohydrolysis liquor was filtered through $0.45-\mu \mathrm{m}$ membranes to measure the glucose, xylose, acetic acid, furfural, and hydroxymethylfurfural (HMF) by highperformance liquid chromatography (HPLC). Other aliquot was used for oligosaccharide quantification by acid posthydrolysis ( $4 \%$ of $\mathrm{H}_{2} \mathrm{SO}_{4}, 121{ }^{\circ} \mathrm{C}$ for $20 \mathrm{~min}$ ), filtered
Table 1 Composition of Eucalyptus globulus wood, EGW $(\mathrm{g} / 100 \mathrm{~g}$ of wood in oven-dry basis), hydrothermally pretreated EGW (g/100 g of pretreated wood in oven-dry basis), and autohydrolysis liquor $(\mathrm{g} / \mathrm{L})$

\begin{tabular}{lcc}
\hline Solid yield, SY (g of pretreated EGW/100 g of EGW) & 71.66 \\
Nonvolatile compounds (g/100 g of EGW) & 18.63 \\
a. Chemical composition of EGW and pretreated EGW & or solid phase after treatment $(\mathrm{g} / 100 \mathrm{~g}$, oven dry basis) \\
& EGW & Pretreated EGW $\left(\mathrm{T}_{\text {max }} 210{ }^{\circ} \mathrm{C}\right)$ \\
Glucan & 44.7 & 59.26 \\
Xylan & 16.01 & 1.95 \\
Arabinan & 1.09 & 0 \\
Acetyl groups & 2.96 & 0.29 \\
Klason lignin & 27.7 & 33.6 \\
Extractives & 2.1 & - \\
Ash & 0.2 & - \\
b. Chemical composition of liquid phase or autohydrolysis liquor $(\mathrm{g} / \mathrm{L})$ \\
Glucooligosaccharides & 1.15 \\
Xylooligosaccharides & & 8.97 \\
Arabinoologosaccharides & & 0 \\
Acetyl groups & & 2.55 \\
Glucose & 0.64 \\
Xylose & 8.85 \\
Arabinose & 0.18 \\
Acetic acid & 3.11 \\
HMF & 0.33 \\
Furfural & 1.66 \\
\hline
\end{tabular}


through $0.45 \mu \mathrm{m}$ and analyzed by HPLC. The oligomer concentration was determined by difference before and after posthydrolysis. A third aliquot was dried at $105^{\circ} \mathrm{C}$ to constant weight for non-volatile compound (NVC) determination.

\section{Evaluation of Stress Conditions on Simultaneous Saccharification and Fermentation Assays: Experimental Plan}

The evaluation of ethanol production in SSF process was carried using a Box-Behnken design (3 factors and central point with 3 replicates, accounting for 15 total experiments). Three independent variables related with stress conditions were studied: temperature $\left(\mathrm{T},{ }^{\circ} \mathrm{C}\right)$, percentage of autohydrolysis liquor (AL, $\mathrm{g}$ of liquor/100 $\mathrm{g}$ of liquid in SSF or \%), and liquid-tosolid ratio (LSR, g of liquid in SSF/g of pretreated EGW solid on dry basis). The variable LSR is inversely proportional to percentage of solids and it can be calculated as follows:

$\%$ solid loading $=\frac{1}{L S R} \cdot 100$

Table 2 shows the fixed, independent, and dependent variables used in this work, as well as the range studied. The values of LSR and percentage of AL analyzed in this work were chosen in basis of previous experience. Thereby, lower level of LSR was chosen because it was previously shown to be feasible even though in different process conditions (washed pretreated EGW solid was used as substrate by itself without the addition of autohydrolysis liquor as liquid in SSF [25]). On the other hand, $60 \%$ of AL was selected as minimum level of inhibitor loading since this was successfully assayed by Kelbert et al. [23]. Taking into account that the temperature could have synergetic effect on the other two variables, a wide range of temperature between 30 and $38^{\circ} \mathrm{C}$ was assayed.

\section{Microorganism and Yeast Cultivation}

The strain used in this work was $S$. cerevisiae PE-2, isolated from Brazilian bioethanol industry [16]. The industrial yeast was maintained at $4{ }^{\circ} \mathrm{C}$ in agar YPD $(2 \%$ of peptone, $2 \%$ of glucose, $2 \%$ of agar, and $1 \%$ of yeast extract) plates. For inoculum preparation, cells were pitched in 1-L Erlenmeyer flasks (containing $400 \mathrm{~mL}$ of medium composed by $50 \mathrm{~g} / \mathrm{L}$ of glucose, $20 \mathrm{~g} / \mathrm{L}$ of peptone, and $10 \mathrm{~g} / \mathrm{L}$ of yeast extract) and grown at $30^{\circ} \mathrm{C}$ and $150 \mathrm{rpm}$ for $24 \mathrm{~h}$. After that, cells were aseptically collected by centrifugation for $15 \mathrm{~min}$ at $8500 \mathrm{~g}$ and $4{ }^{\circ} \mathrm{C}$ and resuspended in $0.9 \% \mathrm{NaCl}$ to achieve a concentration of $200-\mathrm{mg}$ fresh yeast $/ \mathrm{mL}$. The SSF experiments were started with an initial inoculum concentration of 8-mg fresh yeast $/ \mathrm{mL}$.

\section{Simultaneous SSF Process}

Pretreated EGW solid (unwashed and not dried) and autohydrolysis liquor were mixed at varying LSRs, the calculations were performed in dry basis (Table 2). Different liquor percentages were applied as liquid fraction (AL 60-80\%; Table 2). Liquor was sterilized by filtration $(0.22 \mu \mathrm{m})$ to avoid additional sugar degradation, and pretreated EGW was sterilized by autoclave $\left(121^{\circ} \mathrm{C}, 20 \mathrm{~min}\right)$. $\mathrm{pH}$ was adjusted to 4.8 , using $0.05 \mathrm{~N}$ of sodium citrate buffer. SSF assays were carried out in 100-mL Erlenmeyer flasks in an orbital incubator (150 rpm). The enzymes Cellic Ctec2 and HTec2 (kindly supplied by Novozymes, Bagsvaerd, Denmark) were added to SSF assays at moderate enzyme to substrate ratio of 22.5 FPU/g and $500 \mathrm{UI} / \mathrm{g}$ for cellulase and xylanase, respectively [24]. Enzyme activities of cellulase (120 FPU/mL), $\beta$ glucosidase $(779.8 \mathrm{UI} / \mathrm{mL})$, and xylanase $(1690 \mathrm{UI} / \mathrm{mL})$ were measured following standard procedures [26-28].

SSF experiments were supplemented with agro-industrial byproducts (corn steep liquor, cheese whey, yeast extract, urea, and $\mathrm{K}_{2} \mathrm{O}_{5} \mathrm{~S}_{2}$ ) optimized previously [23]. Raw yeast extract (kindly provided by Fermentum Lda. microbrewery, Portugal) was dried at $60{ }^{\circ} \mathrm{C}$ until no weight variation, crushed, sieved, and supplemented to SSF experiments with concentration of $4.1 \mathrm{~g} / \mathrm{L}$. Cheese whey was kindly provided by Quinta dos Ingleses (Agro-Livestock Company, Portugal) and used directly in a concentration of $16.5 \mathrm{~g} / \mathrm{L}$. Cheese whey and yeast extract were pasteurized at $60{ }^{\circ} \mathrm{C}$ for $60 \mathrm{~min}$ and added aseptically to the SSF experiments. Corn steep liquor and $\mathrm{K}_{2} \mathrm{O}_{5} \mathrm{~S}_{2}$ solution were autoclaved $\left(121^{\circ} \mathrm{C}, 20 \mathrm{~min}\right)$ and added to achieve a final concentration in SSF experiments of 5.8 and $0.33 \mathrm{~g} / \mathrm{L}$, respectively. Urea was sterilized by filtration $(0.22 \mu \mathrm{m})$ and added to the SSF experiment $(0.86 \mathrm{~g} / \mathrm{L})$.

SSF assays were conducted in Erlenmeyer flasks with perforated rubber stoppers enclosing glycerol-filled air locks to allow exhaustion of $\mathrm{CO}_{2}$ while avoiding entrance of air. Samples were withdrawn at 0, 7, 23, 31, 47, 71, 96, 122, and $143 \mathrm{~h}$, centrifuged (8000 for $10 \mathrm{~min}$ ) and analyzed by HPLC for glucose, xylose, acetic acid, and ethanol concentration.

In order to evaluate the pretreatment and SSF process, several parameters were determined to enable data interpretation. Cellulose to ethanol conversion (CEC, $\mathrm{g}$ of ethanol/ $100 \mathrm{~g}$ of ethanol potential) was calculated as follows (NREL/TP-51042630):

Cellulose to Ethanol Conversion

$$
=\frac{[\mathrm{EtOH}] \mathrm{f}-[\mathrm{EtOH}] 0}{0.51 \cdot \mathrm{f}[\text { Biomass }] \cdot 1.111} \cdot 100 \%
$$

where $[\mathrm{EtOH}] \mathrm{f}$ is the ethanol concentration at the end of the fermentation $(\mathrm{g} / \mathrm{L}) ;[\mathrm{EtOH}] 0$ is the ethanol concentration at the beginning of the fermentation $(\mathrm{g} / \mathrm{L})$ which should be zero; 
Table 2 Operational conditions used on study of simultaneous saccharification and fermentation (SSF) of hydrothermally pretreated EGW

\begin{tabular}{|c|c|c|}
\hline & Abbreviated name & Values or range \\
\hline \multicolumn{3}{|l|}{ Fixed variables } \\
\hline $\mathrm{pH}$ of SSF assays & & 5 \\
\hline Agitation (rpm) & & 150 \\
\hline \multicolumn{3}{|l|}{ Enzyme loadings } \\
\hline Cellic Ctec2 (FPU/g) & & 22.5 \\
\hline Cellic Htec2 (UI/g) & & 500 \\
\hline \multicolumn{3}{|l|}{ Independent variables } \\
\hline Temperature $\left({ }^{\circ} \mathrm{C}\right)$ & $\mathrm{T}$ or $\mathrm{x}_{1}$ & $30-38$ \\
\hline $\begin{array}{l}\text { Percentage of autohydrolysis Liquor ( } \mathrm{g} \text { of liquor/100 } \mathrm{g} \text { of liquid in } \\
\text { SSF or \%) }\end{array}$ & $\mathrm{AL}$ or $x_{2}$ & $60-80$ \\
\hline Liquid-to-solid ratio (g of liquid in SSF/g of pretreated EGW solid) & LSR or $\mathrm{x}_{3}$ & $4-6.4$ \\
\hline \multicolumn{3}{|l|}{ Dependent variables } \\
\hline Ethanol concentration at $122 \mathrm{~h}(\mathrm{~g} / \mathrm{L})$ & $\mathrm{EC}_{122}$ or $\mathrm{y}_{1}$ & \\
\hline Cellulose to ethanol conversion at $122 \mathrm{~h}(\mathrm{~g} / 100 \mathrm{~g})$ & $\mathrm{CEC}_{122}$ or $\mathrm{y}_{2}$ & \\
\hline Ethanol productivity at $96 \mathrm{~h}(\mathrm{~g} / \mathrm{Lh})$ & $\mathrm{Qp}_{96}$ or $\mathrm{y}_{3}$ & \\
\hline
\end{tabular}

[Biomass] is dry biomass or LCM concentration (corrected by the solubilization of glucan and xylan during the enzymatic saccharification) at the beginning of the fermentation $(\mathrm{g} / \mathrm{L}) ; \mathrm{f}$ is the cellulose fraction of dry biomass $(\mathrm{g} / \mathrm{g}) ; 0.51$ is the factor for glucose to ethanol based on stoichiometric biochemistry of yeast; and 1.111 is the conversion factor of cellulose into equivalent glucose.

Ethanol productivity $\left(\mathrm{Qp}_{\mathrm{t}}, \mathrm{g} / \mathrm{Lh}\right)$ was defined as the ratio between ethanol concentration at time $t\left(\mathrm{E}_{\mathrm{t}}\right)$ and total SSF time, and it was calculated as follows:

$Q p_{t}=\frac{E_{t}}{t}$

\section{Fitting of Data and Modeling}

To obtain the responses of ethanol production, cellulose to ethanol conversion, and ethanol productivity, experimental data were fitted to the proposed models using commercial software (STATISTICA 7 and Statgraphics Plus 5.1). Response surface methodology (RSM) was used for optimization of studied variables.

\section{Analytical Methods}

Samples from analytical composition of raw material, pretreated EGW solid, autohydrolysis liquor, and SSF assays were analyzed for glucose, xylose, acetic acid, hydroxymethylfurfural (HMF), furfural and ethanol by highperformance liquid chromatography (HPLC) using a Varian MetaCarb $87 \mathrm{H}$ column (300x7.8 mm), eluent $\mathrm{H}_{2} \mathrm{SO}_{4} 0.005 \mathrm{M}$ at $60{ }^{\circ} \mathrm{C}$, at a flow rate of $0.7 \mathrm{~mL} / \mathrm{min}$ with a Jasco 830 -IR refractive-index detector (for sugars and acetic acid) and UV detector JASCO set at $210 \mathrm{~nm}$ (for furfural and HMF).

\section{Results and Discussion}

\section{Hydrothermal Pretreatment of Eucalyptus globulus Wood: Chemical Composition}

Conditions of hydrothermal treatment were chosen in basis of previous work in which the highest recovery of polysaccharides (measured as glucose from enzymatic hydrolysis of cellulose and as sum of xylose and xylooligosaccharides from liquid phase after pretreatment) was attained [4]. Table 1 shows the chemical composition of raw material, pretreated EGW solid, and autohydrolysis liquor. After treatment, $95 \%$ of cellulose and $87 \%$ of lignin were recovered quantitatively in solid phase and $81.1 \%$ of xylan was solubilized into xylose and xylooligosaccharides achieving a concentration of 8.89 and $8.97 \mathrm{~g} / \mathrm{L}$, respectively. As consequence of pretreatment hardness, hexoses and pentoses were dehydrated to HMF and furfural (0.66 and $1.66 \mathrm{~g} / \mathrm{L})$, respectively. In addition, the acetyl groups were released to autohydrolysis liquor in the form of acetic acid achieving a concentration of $3.11 \mathrm{~g} / \mathrm{L}$. These inhibitor degradation products represented $25 \%(w / w)$ of total non-volatile compounds in the autohydrolysis liquor. Chromatogram of autohydrolysis liquor is shown in Fig. S1 of supplementary data. The chemical composition of autohydrolysis liquor and pretreated EGW solid is typically of hardwoods and is comparable with previous reported data [29]. The pretreated EGW was directly 
used as substrate in an SSF process without washing and drying steps avoiding additional processing cost which would improve the implementation of a large-scale industrial process.

\section{Simultaneous Saccharification and Fermentation Assays of Pretreated EGW Solid Using Autohydrolysis Liquor as Liquid Medium}

In order to evaluate operational conditions of SSF process, pretreated EGW solid (unwashed and not dried) was mixed with autohydrolysis liquor under conditions described in Tables 2 and 3. This substrate while having carbon source is nutritionally deprived compromising the good performance of the yeast strain that has to deal simultaneously with different stress factors. Currently, byproducts from agro-food industries are generated in considerable quantities worldwide [30], being their use as nutritional source an attractive alternative to attain more cost-effective process. Corn steep liquor (byproduct of corn wet milling) is a clear example of this, used commercially as a supplement to growth media. In this context, low-cost nutritional supplementation (composed by corn steep liquor, cheese whey, raw yeast extract, urea, and $\mathrm{K}_{2} \mathrm{O}_{5} \mathrm{~S}_{2}$ ), previously optimized [23], was added to improve fermentation rates. Industrial S. cerevisiae PE2 strain was chosen on the basis of previous screening using the same autohydrolysis liquor at $30{ }^{\circ} \mathrm{C}[16]$, since it showed higher fermentation performance comparing to other strains isolated from industrial environments (cachaça, first-generation bioethanol and cacao industries) and to laboratorial strains.

Glucose concentration (data not shown) was consumed within the first $8 \mathrm{~h}$ for experiments carried out at $30{ }^{\circ} \mathrm{C}$ independently of inhibitor loading (autohydrolysis liquor) and at $34{ }^{\circ} \mathrm{C}$ for the $60 \%$ of AL. On the other hand, the glucose was consumed within $48 \mathrm{~h}$ in the experiments performed at $34^{\circ} \mathrm{C}$ for the other percentages of AL at LSR $>4 \mathrm{~g} / \mathrm{g}$ and at $38^{\circ} \mathrm{C}$ for 60 and $70 \%$ of AL. It is important to highlight that the glucose was not totally consumed in SSF assays at $38{ }^{\circ} \mathrm{C}$, for the 70 and $80 \% \mathrm{AL}$ and LSR of 4 and $5.2 \mathrm{~g} / \mathrm{g}$ (intermediate and extreme conditions of the experimental design) in which the glucose was accumulated to 58 and $80 \mathrm{~g} / \mathrm{L}$ in the late fermentation phase. This low fermentation performance was also observed by Zhu et al. [31] using diluted acid pretreated corn stover at $38^{\circ} \mathrm{C}$ probably due to low viability of the yeast strain. On the other hand, in this work, glucose was consumed before $96 \mathrm{~h}$ of saccharification and fermentation when the temperature was $34{ }^{\circ} \mathrm{C}$ and the autohydrolysis liquor was $80 \%$. These results show a clear influence of temperature on glucose consumption by the industrial strain in presence of high percentage of autohydrolysis liquor. More inhibitory effect of ethanol concentration with an increase of temperature has been reported by different authors [32, 33]. The same synergistic effect pattern of autohydrolysis liquor percentage and temperature has been previously reported in which an increase of the inhibitor liquor effect could be observed with the rise of temperature [34]. High temperature and presence of inhibitor compounds induce common stress responses to protect yeast cell from damage associated with them [35].

Xylose concentration (data not shown) varied in the range of $10.3-23.1 \mathrm{~g} / \mathrm{L}$, achieving a complete hydrolysis of xylooligosaccharides into xylose. The highest values of xylose were obtained in experiments 4,8 , and 12 where the temperature $\left(34\right.$ and $\left.38^{\circ} \mathrm{C}\right)$ and autohydrolysis liquor percentage (70 and $80 \%$ ) were higher. This fact can be related with
Table 3 Box-Behnken experimental design employed to assess the simultaneous saccharification and fermentation of hydrothermally pretreated EGW under stress conditions of temperature $(\mathrm{T})$, presence of inhibitors (AL), and high solid loadings (LSR)

\begin{tabular}{lllllll}
\hline Run & $\mathrm{T}\left({ }^{\circ} \mathrm{C}\right), \mathrm{x}_{1}$ & $\mathrm{AL}^{\mathrm{a}}(\%), \mathrm{x}_{2}$ & $\mathrm{LSR}^{\mathrm{b}}(\mathrm{g} / \mathrm{g}), \mathrm{x}_{3}$ & $\mathrm{EC}_{122}(\mathrm{~g} / \mathrm{L}), \mathrm{y}_{1}$ & $\mathrm{CEC}_{122}(\mathrm{~g} / 100 \mathrm{~g}), \mathrm{y}_{2}$ & $\mathrm{Qp}_{96}(\mathrm{~g} / \mathrm{Lh}), \mathrm{y}_{3}$ \\
\hline 1 & $30(-1)$ & $60(-1)$ & $5.2(0)$ & 46.0 & 79.8 & 0.427 \\
2 & $38(1)$ & $60(-1)$ & $5.2(0)$ & 47.3 & 82.0 & 0.478 \\
3 & $30(-1)$ & $80(1)$ & $5.2(0)$ & 44.5 & 77.2 & 0.413 \\
4 & $38(1)$ & $80(1)$ & $5.2(0)$ & 12.4 & 21.5 & 0.111 \\
5 & $30(-1)$ & $70(0)$ & $6.4(1)$ & 38.2 & 79.8 & 0.332 \\
6 & $38(1)$ & $70(0)$ & $6.4(1)$ & 41.0 & 85.6 & 0.373 \\
7 & $30(-1)$ & $70(0)$ & $4(-1)$ & 53.6 & 74.1 & 0.519 \\
8 & $38(1)$ & $70(0)$ & $4(-1)$ & 10.3 & 14.2 & 0.092 \\
9 & $34(0)$ & $60(-1)$ & $6.4(1)$ & 46.2 & 96.5 & 0.440 \\
10 & $34(0)$ & $80(1)$ & $6.4(1)$ & 42.9 & 89.7 & 0.398 \\
11 & $34(0)$ & $60(-1)$ & $4(-1)$ & 59.2 & 81.9 & 0.614 \\
12 & $34(0)$ & $80(1)$ & $4(-1)$ & 48.5 & 67.0 & 0.072 \\
13 & $34(0)$ & $70(0)$ & $5.2(0)$ & 47.8 & 82.9 & 0.464 \\
14 & $34(0)$ & $70(0)$ & $5.2(0)$ & 46.5 & 80.6 & 0.467 \\
15 & $34(0)$ & $70(0)$ & $5.2(0)$ & 48.1 & 83.5 & 0.492 \\
\hline
\end{tabular}

${ }^{\text {a }}$ Percentage of autohydrolysis liquor: $\mathrm{g}$ of liquor/100 $\mathrm{g}$ of liquid in SSF

${ }^{b}$ Ratio between $g$ of liquid (composed by different percentages of AL)/g of pretreated EGW 
higher autohydrolysis liquor percentage (containing xylose and xylooligosaccharides) and favorable conditions for enzyme activity (temperature $>30^{\circ} \mathrm{C}$ ), contributing to the hydrolysis of the enduring xylan in the pretreated EGW biomass by cellulases and hemicellulases. Regarding acetic acid, the concentration was almost constant during SSF process, with concentrations in the range of $2.97-3.95 \mathrm{~g} / \mathrm{L}$.

Figure 2 displays the time course of ethanol production for all conditions studied in this work, in which different lag phases of SSF assays can be observed, directly related with the glucose uptake discussed previously. Furan compounds (furfural and HMF) are reduced to less inhibitor alcohols by yeast, being the main cause for different lag phase times in ethanol fermentations at different percentages of autohydrolysis liquor (containing inhibitor compounds) [36]. Variation in the lag phases between 1.5 and $25 \mathrm{~h}$ were also reported for fermentation of spruce hydrolysate at 0,25 , and $50 \%$ and $35{ }^{\circ} \mathrm{C}$, as well as absence of growth with $80 \%$ of hydrolysate after $140 \mathrm{~h} \mathrm{[36].}$
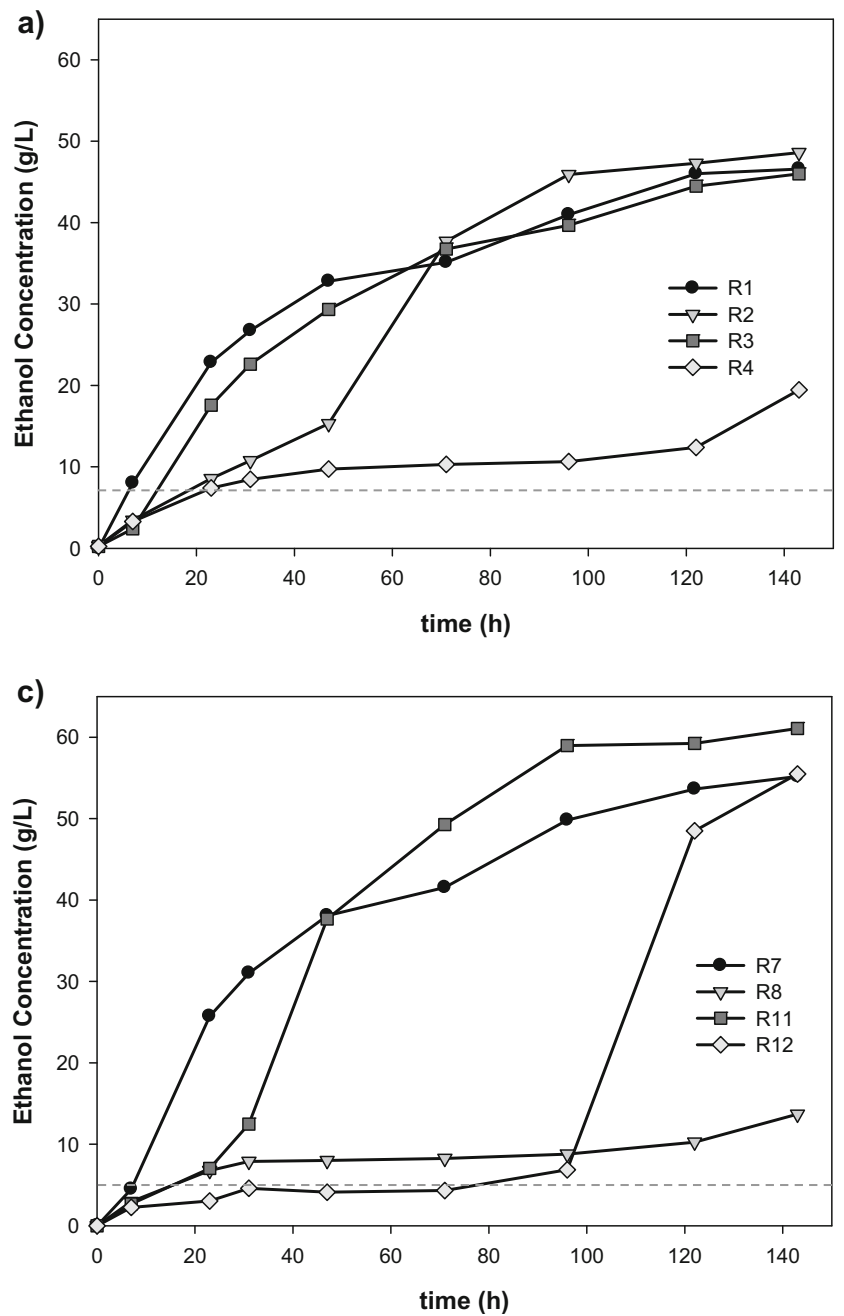

In this work, most experiences entered stationary phase at $96 \mathrm{~h}$ of saccharification and fermentation (Fig. 2), in which the ethanol productivity $\left(\mathrm{Qp}_{96}\right)$ was calculated and listed in Table 3 . Results show that the highest productivity value $(0.614 \mathrm{~g} / \mathrm{Lh})$ was obtained at intermediate temperatures $\left(34{ }^{\circ} \mathrm{C}\right)$, low inhibitory loading $(60 \%$ of $\mathrm{AL})$ and the highest solid loading ( $(\mathrm{SR}=4 \mathrm{~g} / \mathrm{g}$ ). Low liquid-to-solid ratio (corresponding to high solid loading) and low percentage of autohydrolysis liquor allowed good yeast performance due to higher substrate availability and reduced furan compound inhibition, alongside with intermediate temperature which allows good enzymatic performance without compromising yeast viability. As a general trend, ethanol productivities $>0.4 \mathrm{~g} / \mathrm{Lh}$ were achieved at 30 and $34{ }^{\circ} \mathrm{C}$ using LSR of 4 and $5.2 \mathrm{~g} / \mathrm{g}$.

In this work, the maximal concentration of ethanol for each SSF assay was achieved at $143 \mathrm{~h}$ and varied in the range of 13.7-61.1 $\mathrm{g} / \mathrm{L}$ (CEC of 18.9 and $84.4 \%$ ) corresponding to experiments 8 and 11, respectively. Maximal ethanol concentration was obtained for the highest solid loading (LSR $=4 \mathrm{~g}$ /
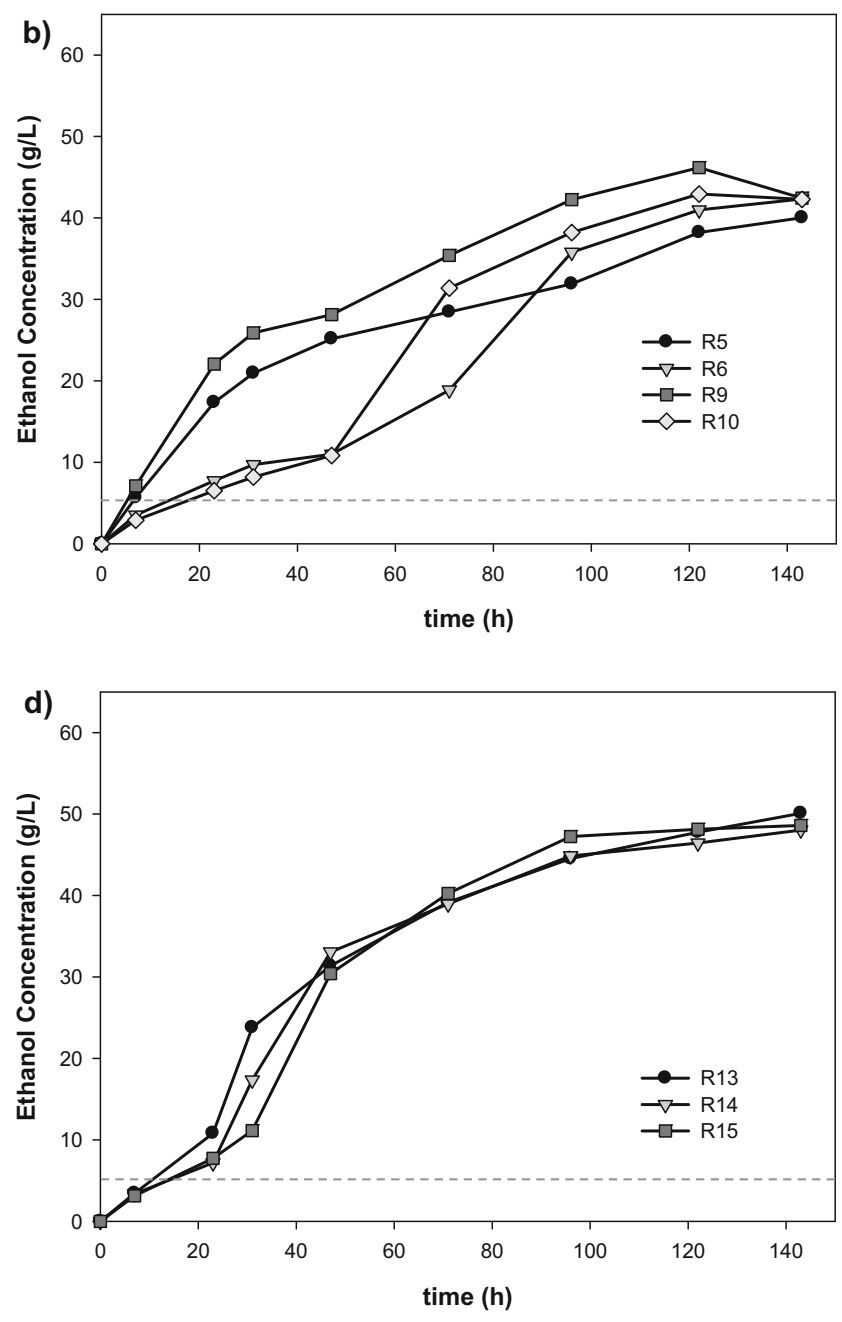

Fig. 2 Time course of ethanol concentration of simultaneous saccharification and fermentation (SSF) assays (runs 1-15 listed in Table 3), dotted line is indicating lag phases 
$\mathrm{g})$, intermediate temperature $\left(34^{\circ} \mathrm{C}\right)$ and lowest percentage of autohydrolysis liquor, corresponding to better performing conditions previously discussed regarding productivity. In comparison with results obtained at $30{ }^{\circ} \mathrm{C}$, the difference in the ethanol concentration could be due to a deficient enzymatic hydrolysis taking into account the low temperature. Ethanol concentration higher than $55 \mathrm{~g} / \mathrm{L}$ was obtained in experiments 7,11 , and 12 in which the LSR was $4 \mathrm{~g} / \mathrm{g}$ or $25 \%$ of solids. Moreover, ethanol concentration $>40 \mathrm{~g} / \mathrm{L}$ was obtained at $143 \mathrm{~h}$ in all studied conditions except for experiments 4 and 8 , carried out at $38{ }^{\circ} \mathrm{C}$ with 70 and $80 \%$ of $\mathrm{AL}$. Chromatogram of the sample from the SSF experiment (run 9 at $47 \mathrm{~h}$ ) is shown in S2 of supplementary data.

Regarding the cellulose to ethanol conversion, the highest values were achieved for the lowest solid loading $(\mathrm{LSR}=6.4 \mathrm{~g} / \mathrm{g}$ ) independently of temperature and percentage of autohydrolysis liquor. This effect of the solid loading on cellulose to ethanol conversion can be linked to a reduction on enzymatic efficiency. Higher solid loadings can influence negatively the mixing properties in the fermentation medium, reducing enzymatic access to the cellulose and conversion efficiency.

\section{Response Surface Methodology Assessment}

Screening studies for tolerant $S$. cerevisiae are generally aimed at individual stresses, while the resistance to multiple stresses has received less attention [37-39]. This integrated approach should be considered since the combined effect of stresses is the great challenge of saccharification and fermentation process for industrial lignocellulosic ethanol production. Moreover, when taking into account SSF processes, the imposed stresses can affect simultaneously the enzyme and yeast performance, amplifying the need for an integrated study taking into account multiple inhibitions during the whole cellulose to ethanol conversion process. The influence of SSF operational conditions on ethanol production, ethanol conversion, and ethanol productivity presents an elevate grade of complexity due to the variable interaction, as it can be seen in Tables 3 and 4. In this sense, the RSM is a useful tool for the easy visualization of independent variable effects on dependent variables as well as for the prediction of results within the studied range [40]. Table 3 recollected the dependent variables studied in this work: ethanol concentration at $122 \mathrm{~h}\left(\mathrm{EC}_{122}\right.$ in $\left.\mathrm{g} / \mathrm{L}\right)$, cellulose to ethanol conversion at $122 \mathrm{~h}\left(\mathrm{CEC}_{122}\right.$ in $\left.\mathrm{g} / 100 \mathrm{~g}\right)$, and ethanol productivity at $96 \mathrm{~h}\left(\mathrm{Qp}_{96}\right.$ in $\left.\mathrm{g} / \mathrm{Lh}\right)$. Ethanol concentration and conversion were chosen at $122 \mathrm{~h}$ of saccharification and fermentation as in the next time point, the ethanol concentration started to decrease in some experiments. These experimental variables were correlated with independent variables (T, AL, and LSR) by a second-order polynomial equation, as follows:

$y_{j}=b_{0 j}+\sum_{i=1}^{3} b_{i j} x_{i}+\sum_{i=1}^{3} \sum_{k \geq i}^{3} b_{i k j} x_{i} x_{k}$

where $y_{j}(j=1$ to 3$)$ is the dependent variable; $x_{i}$ or $x_{k}(i$ or $k$ : 1 to $2, k \geq i$ ) are the normalized, independent variables (defined in Table 3 ), and $b_{0 \mathrm{j}} \ldots b_{\mathrm{ikj}}$ are regression coefficients calculated from experimental data by multiple regression using the least-squares method.

Table 4 recollects the regression coefficients $\left(b_{0 j} \ldots b_{23 j}\right)$, the statistical significance (based in the Student's $t$ test), and the statistical significance of the model (based on Fischer's $F$ parameter). The parameters summarized in Table 4 verified the good fitting of dependent and independent variables by the empirical models. The average coefficient $\left(R^{2}\right)$ of the models was $>0.96$ for studied dependent variables, which shows that the model is suitable to represent the correlation among selected variables.

Figure 3 shows a graphic representation of the interaction of temperature, percentage of autohydrolysis liquor, and liquid solid loading on ethanol concentration, fixing three levels $(-1$, 0 , and 1). The linear coefficient was significant at $p \leq 0.05$ for the temperature and percentage of autohydrolysis liquor (Table 4). On the other hand, the quadratic coefficient was significant for temperature and LSR and interaction coefficient for the combination of temperature and LSR (Table 4). Figure 3 a shows the different behaviors obtained at 30, 34, and $38^{\circ} \mathrm{C}$ for LSR and percentage of autohydrolysis liquor on ethanol production. The reported results at $38^{\circ} \mathrm{C}$ showed the clear influence of temperature on ethanol concentration, leading to higher concentration between 30 and $50 \mathrm{~g} / \mathrm{L}$ comparing to results obtained at $30{ }^{\circ} \mathrm{C}$, where concentration of ethanol was in the range of $30-38 \mathrm{~g} / \mathrm{L}$ at high solid loadings $(\mathrm{LSR}=4 \mathrm{~g} / \mathrm{g})$ and percentage of autohydrolysis liquor $<76 \%$. This performance is probably due to a lower enzyme activity at $30{ }^{\circ} \mathrm{C}$, showing that the temperature was a more limiting variable than low LSR (or high solid loading) and percentage of autohydrolysis liquor on ethanol concentration. In fact, Mutturi and Lidén [34] reported a decrease of glucose release $(18 \%)$ of saccharification of pretreated arundo $32{ }^{\circ} \mathrm{C}$ comparing to $39{ }^{\circ} \mathrm{C}$, indicating that yield of ethanol at $32{ }^{\circ} \mathrm{C}$ on SSF process could be significantly lower than at $39^{\circ} \mathrm{C}$. At $34{ }^{\circ} \mathrm{C}$, an ethanol concentration higher than $40 \mathrm{~g} / \mathrm{L}$ was obtained under all conditions. This pattern is in agreement with reported works in which the selected temperature for SSF process is usually $35{ }^{\circ} \mathrm{C}[36,41]$. Results indicate that the inhibitor effect is more expressive at higher temperatures. High temperature stress has great influence on cellular processes: inhibition of cell division, imbalance of protein homeostasis, and difficulty on coupling of oxidative 
Table 4 Regression coefficients and statistical parameters measuring the correlation and significance of models for independent variables: liquid/ solid ratio (LSR), temperature $(\mathrm{T})$, and percentage of autohydrolysis liquor (AL)

\begin{tabular}{|c|c|c|c|}
\hline Model parameters & $\mathrm{E}_{122 \mathrm{~h}}$ or $\mathrm{y}_{1}(\mathrm{~g} / \mathrm{L})$ & $\mathrm{CEC}_{122 \mathrm{~h}}$ or $\mathrm{y}_{2}(\mathrm{~g} / 100 \mathrm{~g})$ & $\mathrm{Qp}_{96 \mathrm{~h}}$ or $\mathrm{y}_{3}(\mathrm{~g} / \mathrm{Lh})$ \\
\hline $\mathrm{b}_{0}$ (Intercept) & 47.447 & 82.335 & 0.474 \\
\hline \multicolumn{4}{|l|}{ Linear } \\
\hline $\mathrm{T}\left(\mathrm{b}_{1}\right)$ & $-8.926^{\mathrm{b}}$ & $-13.453^{\mathrm{a}}$ & $-0.080^{\mathrm{a}}$ \\
\hline $\operatorname{AL}\left(b_{2}\right)$ & $0.4118^{\mathrm{b}}$ & $-10.599^{\mathrm{b}}$ & $-0.121^{\mathrm{a}}$ \\
\hline $\operatorname{LSR}\left(b_{3}\right)$ & 1.769 & $-14.282^{\mathrm{a}}$ & $-0.031^{\mathrm{c}}$ \\
\hline \multicolumn{4}{|l|}{ Quadratic } \\
\hline $\mathrm{T}\left(\mathrm{b}_{11}\right)$ & $-6.298^{b}$ & $-18.766^{\mathrm{b}}$ & $-0.085^{\mathrm{b}}$ \\
\hline $\operatorname{AL}\left(b_{22}\right)$ & $-11.675^{\mathrm{c}}$ & 1.575 & -0.033 \\
\hline LSR ( $\left.b_{33}\right)$ & -0.003 & -0.150 & $-0.061^{\mathrm{b}}$ \\
\hline \multicolumn{4}{|l|}{ Interaction } \\
\hline $\mathrm{T} \times \mathrm{AL}\left(\mathrm{b}_{12}\right)$ & -8.342 & $-14.476^{\mathrm{b}}$ & $-0.088^{\mathrm{a}}$ \\
\hline $\mathrm{T} \times \operatorname{LSR}\left(\mathrm{b}_{13}\right)$ & $-11.540^{\mathrm{b}}$ & $-16.436^{\mathrm{b}}$ & $-0.117^{\mathrm{a}}$ \\
\hline $\operatorname{AL} \times \operatorname{LSR}\left(b_{23}\right)$ & -1.872 & -2.015 & $-0.125^{\mathrm{a}}$ \\
\hline $\mathrm{F}$ & 5.846 & 9.628 & 24.075 \\
\hline $\mathrm{R}^{2}$ & 0.913 & 0.945 & 0.977 \\
\hline Significance level & $>96$ & $>98$ & $>99$ \\
\hline
\end{tabular}

${ }^{a}$ Coefficient significant at $\geq 99 \%$ confidence level

${ }^{\mathrm{b}}$ Coefficient significant at $\geq 95 \%$ confidence level

${ }^{\mathrm{c}}$ Coefficient significant at $\geq 90 \%$ confidence level
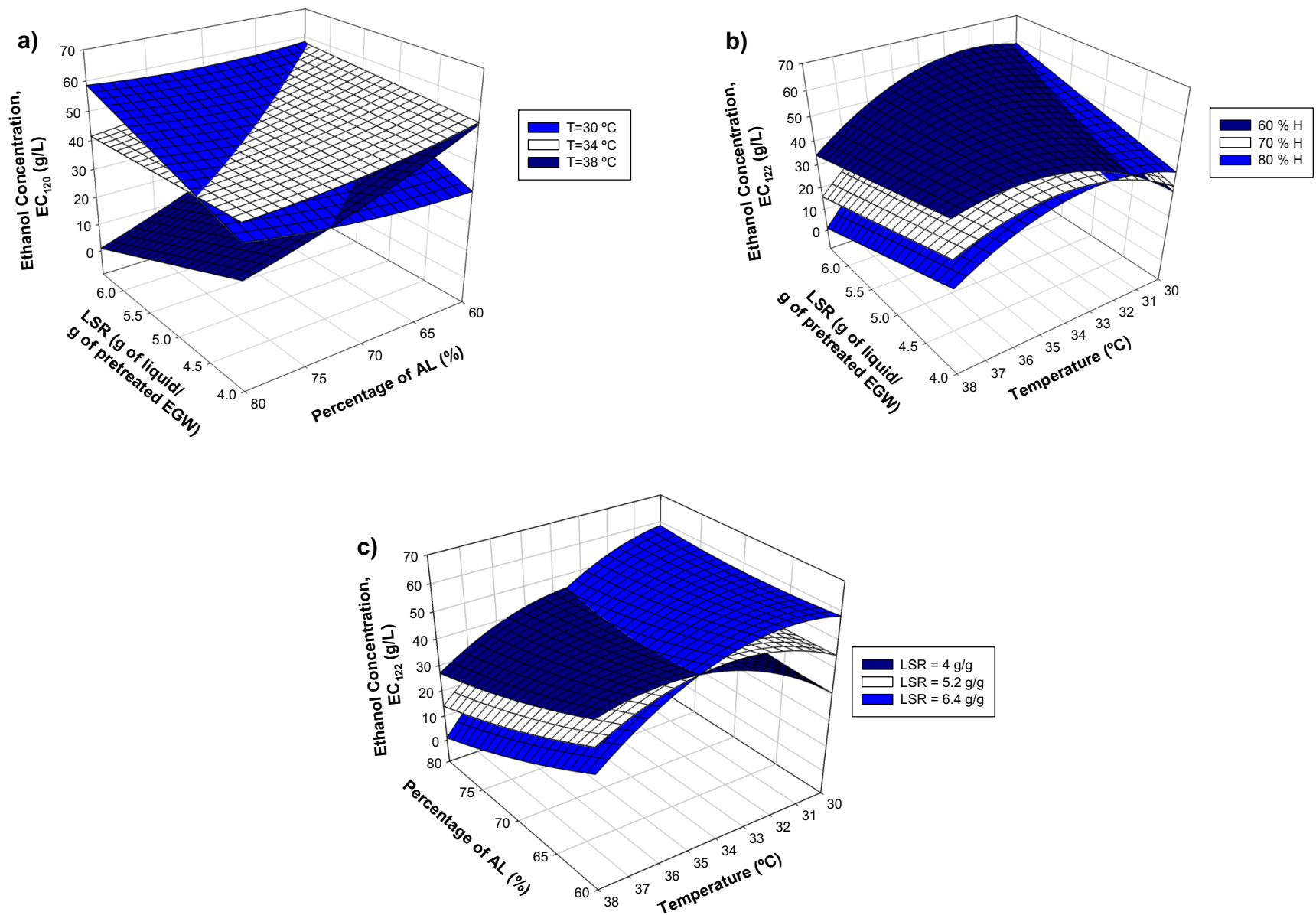

Fig. 3 Response surface of ethanol concentration at $122 \mathrm{~h}\left(\mathrm{EC}_{122}\right)$ of simultaneous saccharification and fermentation process on a percentage of autohydrolysis liquor (AL) and LSR (fixed temperature at 30,34, and
$38{ }^{\circ} \mathrm{C}$ ); $\mathbf{b}$ autohydrolysis liquor and temperature (fixed percentage of AL at 60,70 , and $80 \%$ ); and $\mathbf{c}$ temperature and autohydrolysis liquor (fixed LSR at $4,5.2$, and $6.4 \mathrm{~g} / \mathrm{g}$ ) 
phosphorylation [41] which could hinder the biological detoxification of inhibitor compounds. Studies related with temperature tolerance of $S$. cerevisiae have demonstrated that differences of less than $1{ }^{\circ} \mathrm{C}$ have great influence on growth, nongrowth, and death of yeast at temperature range of $37-43^{\circ} \mathrm{C}$ [42]. Figure 3b, c show ethanol concentration as function of temperature and LSR (fixing the percentage of autohydrolysis liquor at 60,70 , and $80 \%$ ) and temperature and percentage of autohydrolysis liquor (fixing LSR at 4, 5.2, and $6.4 \mathrm{~g} / \mathrm{g}$ ), respectively. At $38^{\circ} \mathrm{C}$, ethanol concentration increased slightly with a decrease of LSR. On the other hand, ethanol concentration decreased for increasing of autohydrolysis liquor percentage. At fixed percentage of autohydrolysis liquor of $60 \%$, ethanol concentration was 1.7 -fold higher at $38{ }^{\circ} \mathrm{C}$ compared to $30{ }^{\circ} \mathrm{C}$. On the other hand, ethanol concentration was 1.4fold higher at $30^{\circ} \mathrm{C}$ than $38{ }^{\circ} \mathrm{C}$ with $80 \%$ of autohydrolysis liquor. In addition, differences in the autohydrolysis liquor loading of $5 \%$ (60 to $65 \%$ of AL) implied a decrease of ethanol concentration of $39.2 \%$ ( 34 to $24.4 \mathrm{~g} / \mathrm{L}$ ). Favaro et al. [38] also reported a decrease of ethanol concentration (43.4 to $18.6 \mathrm{~g} / \mathrm{L}$ ) with 50 and $75 \%$ of sugarcane hydrolysate, respectively, using a thermotolerant $S$. cerevisiae Fm17 strain isolated from grape marc.

Figure 3c shows that ethanol concentration for LSR of $6.4 \mathrm{~g} / \mathrm{g}$ had an almost linear behavior regarding variation of temperature and percentage of autohydrolysis liquor. Nevertheless, LSR of 4 and $5.2 \mathrm{~g} / \mathrm{g}$ show a maximum at $34{ }^{\circ} \mathrm{C}$. The optimal conditions for maximal concentration of ethanol were calculated and predicted a concentration of $58.6 \mathrm{~g} / \mathrm{L}$ under the following conditions: $30{ }^{\circ} \mathrm{C}, 60 \%$ of $\mathrm{AL}$, and $\mathrm{LSR}=6.4 \mathrm{~g} / \mathrm{g}$.

Cellulose to ethanol conversion correlation with independent variables was represented in Fig. 4a in which LSR was fixed at $4 \mathrm{~g} / \mathrm{g}$ (higher solid loadings). As it can be seen, cellulose to ethanol conversion higher than $90 \%$ was obtained in a wide range of operating conditions at temperatures above $31.5^{\circ} \mathrm{C}$. In addition, cellulose to ethanol conversion of $100 \%$ was also achieved for a percentage of autohydrolysis liquor lower than $70 \%$. These results show an interesting range of limiting process conditions (high solid and autohydrolysis liquor loadings) in which ethanol conversion achieves competitive values. This aspect is important from the industrial point of view since the reduction of additional washing steps (using the autohydrolysis liquor) and water consumption (with low liquid-to-solid ratios) without losses on ethanol yield has a direct impact in the economic efficiency of lignocellulosic ethanol processes. A remarkable decrease on ethanol yield was reported by Liu et al. [43] when increasing the solid loading from 20 to $25 \%$ of whole slurry from steamexploded corn cob at $39^{\circ} \mathrm{C}$. For the results hereby presented, the empirical model predicted a maximal ethanol conversion of $100 \%$ using $60 \%$ of autohydrolysis liquor, liquid/solid ratio of $4 \mathrm{~g} / \mathrm{g}$ (or $25 \%$ solids) and temperature of $35.9{ }^{\circ} \mathrm{C}$.
The presence of inhibitors seems more harming at high LSR. This result can be due to lignocellulosic biomass ability to absorb or react with compounds present in the autohydrolysis liquor. Considering that SSF has a solid (lignocellulosic biomass) and a liquid (autohydrolysis liquor) phase, interaction between phases can occur. Compounds present in the autohydrolysis liquor can be absorbed or react with the lignocellulosic biomass, making them less available in the liquid phase and therefore less harmful for the yeast. Liu et al. [43] also observed this behavior at high glucan loading for enzymatic saccharification. However such relation cannot be directly established given that the coefficient for interaction between percentage of autohydrolysis liquor and LSR was not considered statistically significant considering the empirical model for cellulose to ethanol conversion. According to Table 4, linear, quadratic, and interaction coefficients were significant at $p \leq 0.05$ for temperature. Linear coefficients were also significant for variables: percentage of $A L$ and LSR. Moreover, Fig. 4b represents the predicted values of ethanol conversion (CEC) as function of temperature and LSR at fixed $80 \%$ of autohydrolysis liquor (the highest inhibitor loading). Eighty percent of ethanol conversion was achieved at temperature $<36^{\circ} \mathrm{C}$ and LSR of $4 \mathrm{~g} / \mathrm{g}$. These data reveal the influence of autohydrolysis liquor percentage on SSF process since, with washed pretreated EGW (without autohydrolysis liquor) under same conditions of pretreatment $\left(\mathrm{T}_{\max }\right.$ of $\left.210^{\circ} \mathrm{C}\right)$, the ethanol conversion increases with rise of LSR [25], showing a different behavior.

Figure $5 \mathrm{a}, \mathrm{b}$ represents the ethanol productivity fixing the percentage of autohydrolysis liquor in $60 \%$ (in which the ethanol productivity was more elevated) and $L S R=4 \mathrm{~g} / \mathrm{g}$ (the highest solid loading). The interaction of all studied variables had a significant effect $(p \leq 0.01)$ (see Table 4$)$. Maximal ethanol productivity $\left(\mathrm{Qp}_{96}=0.631 \mathrm{~g} / \mathrm{Lh}\right)$ was predicted by the empirical models for the following operational conditions: $31.4{ }^{\circ} \mathrm{C}, 60 \%$ of AL, and LSR $=6.4 \mathrm{~g} / \mathrm{g}$.

Currently, literature collects few studies of lignocellulosic ethanol production with the evaluation of more than one stress factor on simultaneous saccharification and fermentation process $[13,14,38,43,44]$. Most of them follow strategies as screening of industrial strains and/or improvement of strain robustness tools such as evolutionary engineering and/or genome shuffling $[35,36]$. Results obtained in this work with high solid and autohydrolysis liquor loadings can be favorably compared to previously reported data $[38,43]$.

\section{Optimization of Ethanol Production: Operational Conditions Selection and Model Validation}

Ethanol concentration and conversion were maximized by multiple response optimization models. The predicted condition $(55.8 \mathrm{~g} / \mathrm{L}$ and $100 \%$ of conversion) was obtained under the following conditions: temperature of $37^{\circ} \mathrm{C}, 60 \%$ of $\mathrm{AL}$, 
a)

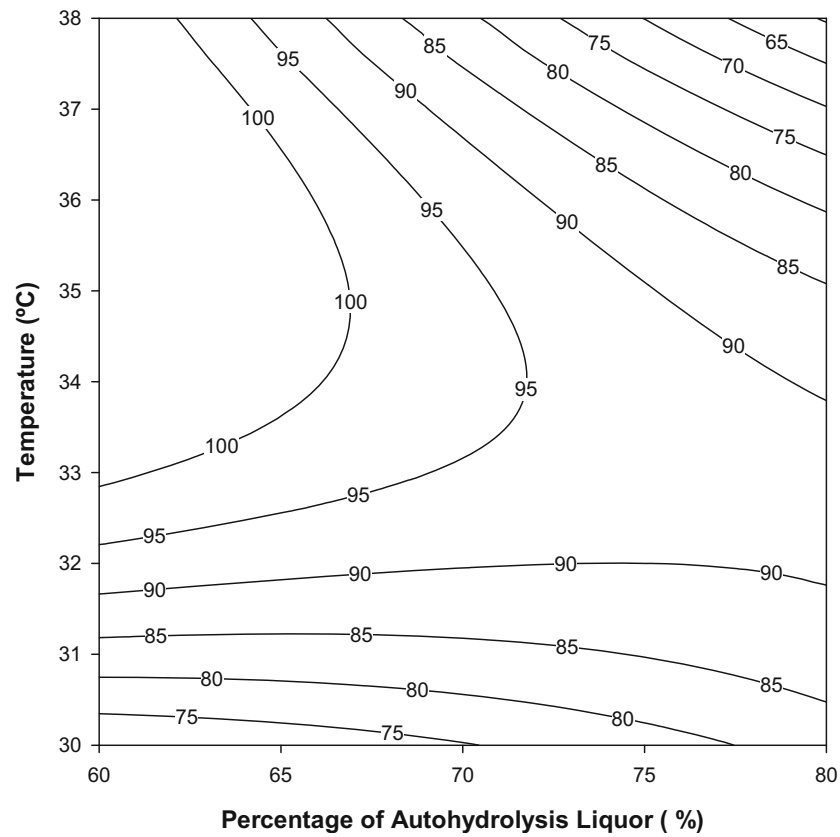

b)

Percentage of Autohydrolysis Liquor $=80 \%$

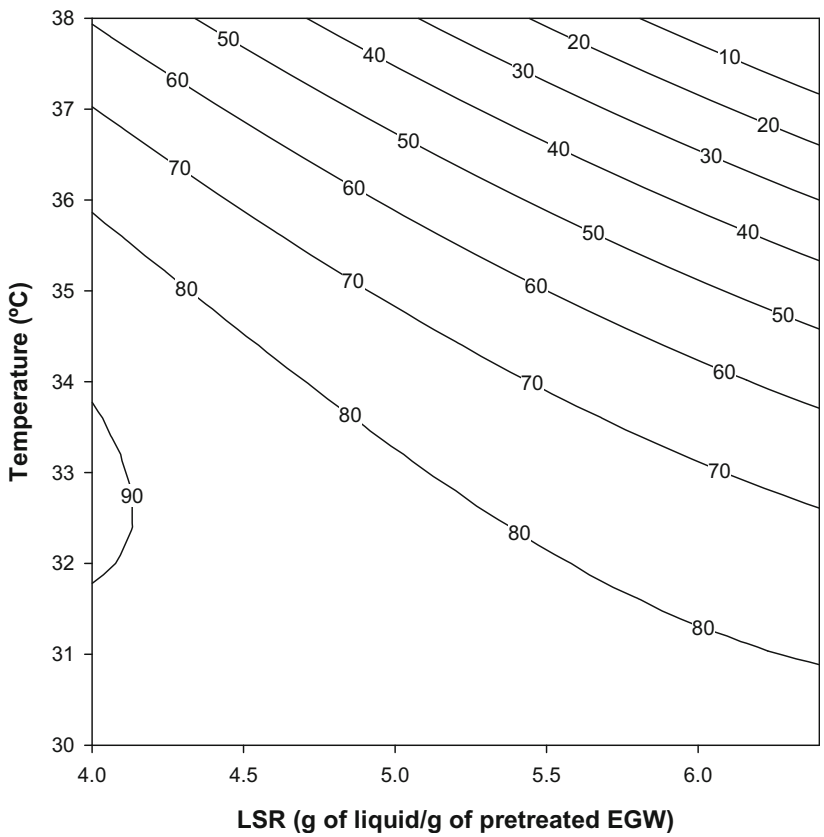

Fig. 4 Response surface of cellulose to ethanol conversion at $122 \mathrm{~h}\left(\mathrm{CEC}_{122}\right)$ of simultaneous saccharification and fermentation process on a temperature and autohydrolysis liquor, AL (fixed LSR at $4 \mathrm{~g} / \mathrm{g}$ ); b temperature and LSR (fixed percentage of AL at $80 \%$ )

and LSR of $6.4 \mathrm{~g} / \mathrm{g}$. In order to validate this optimal condition, an additional experiment was carried out. The experimental validation results were as follows: $53.8 \mathrm{~g} / \mathrm{L}, 85 \%$, and $0.51 \mathrm{~g} /$ Lh, respectively (relative error $\leq 10 \%$ ). In order to compare with separate hydrolysis and fermentation (SHF) process, an additional assay was carried out under optimal conditions. First step of hydrolysis was performed at $50{ }^{\circ} \mathrm{C}$ to favor the enzyme action and the second step of fermentation at $37^{\circ} \mathrm{C}$. a)

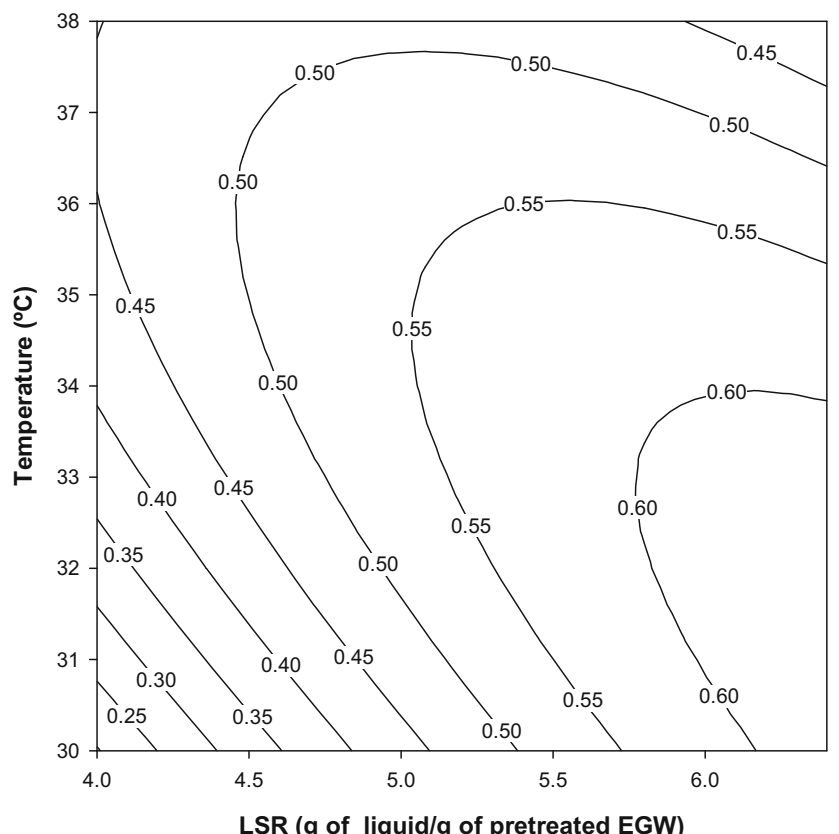

b)

\section{LSR $=4 \mathrm{~g}$ of liquid/g of pretreated EGW}

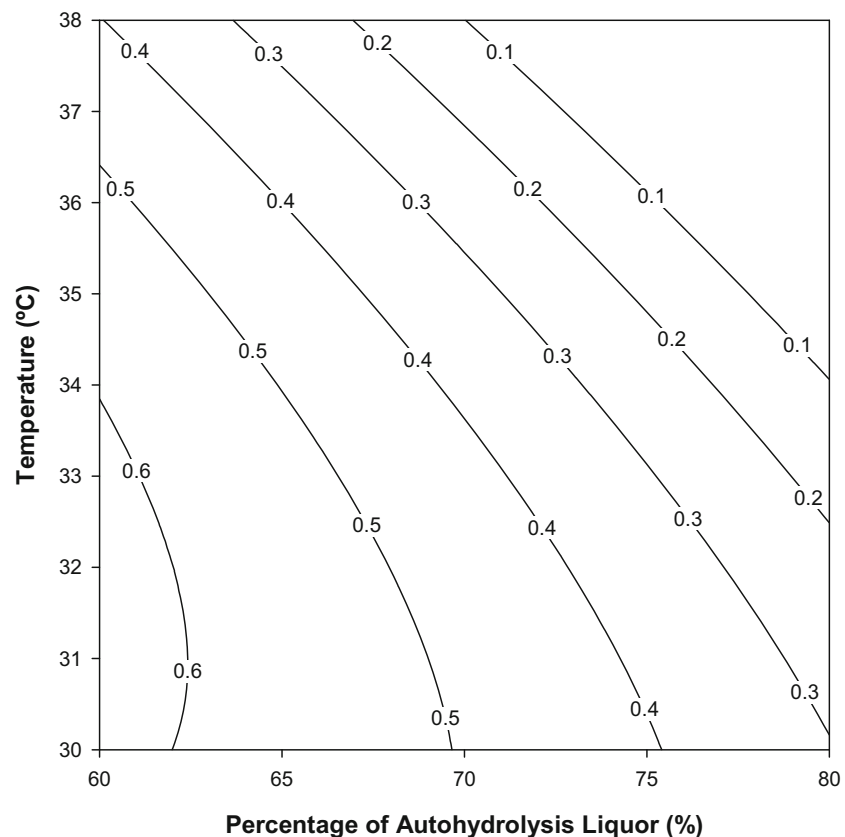

Fig. 5 Response surface of ethanol productivity at $96 \mathrm{~h}\left(\mathrm{Qp}_{96}\right)$ of simultaneous saccharification and fermentation process on a temperature and LSR (fixed $60 \%$ of $\mathrm{AL}$ ); $\mathbf{b}$ temperature and percentage of autohydrolysis liquor (fixed LSR at $4 \mathrm{~g} / \mathrm{g}$ ) 
After $96 \mathrm{~h}$ of enzymatic hydrolysis, $86 \mathrm{~g} / \mathrm{L}$ of glucose was obtained which was used for fermentation. Ethanol concentration was $39.7 \mathrm{~g} / \mathrm{L}$ (corresponding to $74 \%$ of cellulose to ethanol conversion). Data were displayed in supplementary data Fig. S3.

Besides this optimization, in a wide range of restraining conditions of SSF process, suitable results of cellulose to ethanol conversion (60-80\%) were obtained for a temperature range between 36 and $38^{\circ} \mathrm{C}$ using $80 \%$ of $\mathrm{AL}$ at $\mathrm{LSR}=4 \mathrm{~g} / \mathrm{g}$ (or $25 \%$ solid loading). In this study, the complete separation of the liquid and solid phases of the whole slurry was carried out to study the effect of the different stress factors. In a process perspective, partial separation by a simple operation unit like for instance decantation could be conducted to adjust the whole slurry to reach the optimal LSR and percentage of autohydrolysis liquor hereby determined.

\section{Conclusion}

The integrated approach followed in this work addresses the real requirements of lignocellulosic ethanol industry. Synergistic effects between temperature, percentage of autohydrolysis liquor, and liquid/solid ratio and their effect on the responses studied were shown, by the empirical models, as having negative impact on ethanol production, taking into account the whole SSF process. These results indicate a significant influence of temperature on yeast tolerance to inhibitor compounds present in the autohydrolysis liquor. Interestingly, at high solid loadings (LSR of $4 \mathrm{~g} / \mathrm{g}$ ), ethanol conversion is enhanced at high percentage of autohydrolysis liquor compared to results at lower solid loadings (LSR of $6.4 \mathrm{~g} / \mathrm{g}$ ). Overall, the strategy followed in this work (robust industrial S. cerevisiae and low-cost nutritional supplementation) to tackle the challenges identified in lignocellulose-to ethanol processes allowed noticeable results of cellulose to ethanol conversion ( $>90 \%$ ) under quite restrictive SSF process conditions $(80 \%$ of $\mathrm{AL}, \mathrm{LSR}=4 \mathrm{~g} / \mathrm{g}$, and temperatures between 32 and $33.6^{\circ} \mathrm{C}$ ), representing a step forward for the realization of a cost-effective lignocellulose-to-ethanol process.

Acknowledgments The authors thank the financial support from the Strategic Project of UID/BIO/04469/2013 CEB Unit and A Romaní postdoctoral grant funded by Xunta of Galicia (Plan I2C, 2014).

\section{References}

1. Sanna A (2014) Advanced biofuels from thermochemical processing of sustainable biomass in Europe. Bioenergy Res 7(1):36- 47. doi:10.1007/s12155-013-9378-4

2. Radecka D, Mukherjee V, Mateo RQ, Stojiljkovic M, FoulquiéMoreno MR, Thevelein JM (2015) Looking beyond
Saccharomyces: the potential of non-conventional yeast species for desirable traits in bioethanol fermentation. FEMS Yeast Res 15(6):1-13. doi:10.1093/femsyr/fov053

3. Weil J, Westgate P, Kohlmann K, Ladisch MR (1994) Cellulose pretreatments of lignocellulosic substrates. Enzym Microb Technol 16:1002-1004

4. Romaní A, Garrote G, Alonso JL, Parajó JC (2010) Bioethanol production from hydrothermally pretreated Eucalyptus globulus wood. Bioresour Technol 101(22):8706-8712. doi:10.1016/j. biortech.2010.06.093

5. Chandel AK, da Silva SS, Singh OV. Detoxification of lignocellulose hydrolysates: biochemical and metabolic engineering toward white biotechnology. Bioenerg Res 6(1):388-401. doi: 10.1007/ s12155-012-9241-z

6. Almeida JRM, Bertillsson M, Gorwa-Grauslund MF, Gorsich S, Lindén G (2009) Metabolic effects of furaldehydes and impacts on biotechnological processes. Appl Microbiol Biotechnol 82(4): 625-638. doi:10.1007/s00253-009-1875-1

7. Mesa L, González E, Romero I, Ruiz E, Cara C, Castro C (2011) Comparison of process configurations for ethanol production from two-step pretreated sugarcane bagasse. Chem Eng J 175:185-191. doi:10.1016/j.cej.2011.09.092

8. Steensels J, Verstrepen KJ (2014) Taming wild yeast: potential of conventional and nonconventional yeast in industrial fermentations. Annu Rev Microbiol 68:61-80. doi:10.1146/annurev-micro091213-113025

9. Anderson PJ, McNeil K, Watson K (1986) High-efficiency carbohydrate fermentation to ethanol at temperatures above $40{ }^{\circ} \mathrm{C}$ by Kluyveromyces marxianus var. marxianus isolated from sugars mills. Appl Environ Micobiol 51(6):1314-1320. doi: 0099-2240/ 86/061314-07\$02.00/0

10. Kumar S, Dheeran P, Singh SP, Mishra IM, Adhikari DK (2013) Cooling system economy in ethanol production using thermotolerant yeast Kluyveromyces sp. IIPE453. Am J Micobiol Res 1(3):39-44. doi:10.12691/ajmr-1-3-1

11. Su R, Ma Y, Qi W, Zhang M, Wang F, Du R, Yang J, Zhang M, He Z (2013) Ethanol production from high-solid SSCF of alkalinepretreated corncob using recombinant Zymomonas mobilis CP4. Bioenergy Res 6(1):292-299. doi:10.1007/s12155-012-9256-5

12. Modenbach AA, Nokes SE (2013) Enzymatic hydrolysis of biomass at high-solids loadings - a review. Biomass Bioenergy 56: 526-544. doi:10.1016/j.biombioe.2013.05.031

13. Jin M, Sarks C, Gunawan C, Bice BD, Simonett SP, Narasimhan RA, Willis LB, Dale BE, Balan V, Sato T (2013) Phenotypic selection of a wild Saccharomyces cerevisiae strain for simultaneous saccharification and co-fermentation of $\mathrm{AFEX}^{\mathrm{TM}}$ pretreated corn stover. Biotechnol Biofuels 6:108. doi:10.1186/1754-6834-6-108

14. Wimalasena TT, Greetham D, Marvin ME, Liti G, Chandelia Y, Hart A, Louis EJ, Phister TG, Tucker GA, Smart KA (2014) Phenotypic characterisation of Saccharomyces spp. yeast for tolerance to stress encountered during fermentation of lignocellulosic residues to produce bioethanol. Microb Cell Factories 13(1):47. doi:10.1186/1475-2859-13-47

15. Basso LC, De Amorin HV, De Oliveira AJ, Lopes ML (2008) Yeast selection for fuel ethanol production in Brazil. FEMS Yeast Res 8(7):1155-1163. doi:10.1111/j.1567-1364.2008.00428.x

16. Pereira FB, Romaní A, Ruiz HA, Teixeira JA, Domingues L (2014) Industrial robust yeast isolated with great potential for fermentation of lignocellulosic biomass. Bioresour Technol 161:192-199. doi: 10.1016/j.biortech.2014.03.043

17. Field SJ, Ryden P, Wilson D, James SA, Roberts IN, Richardson DJ, Waldron KW, Clarke TA (2015) Identification of furfural resistant strains of Saccharomyces cerevisiae and Saccharomyces paradoxus from a collection of environmental and industrial isolates. Biotechnol Biofuels 8:33. doi:10.1186/s13068-015-0217-z 
18. Costa DA, de Souza CJA, Costa PS, Rodrigues MQRB, dos Santos AF, Lopes MR, Genier HL, Silveira WB, Fietto LG (2014) Physiological characterization of thermotolerant yeast for cellulosic ethanol production. Appl Microbiol Biotechnol 98:3829-3840. doi: 10.1007/s00253-014-5580-3

19. Pereira FB, Guimarães PMR, Teixeira JA, Domingues L (2010) Selection of Saccharomyces cerevisiae strains for efficient very high gravity bio-ethanol fermentation processes. Biotechnol Lett 32(11):1655-1661. doi:10.1007/s10529-010-0330-9

20. Pereira FB, Guimarães PMR, Teixeira JA, Dominghes L (2011) Robust industrial Saccharomyces cerevisiae strains for very high gravity bio-ethanol fermentations. J Biosci Bioeng 112(2):130 136. doi:10.1016/j.jbiosc.2011.03.022

21. Silva Filho EA, Meelo HF, Antunes DF, Santos SKB, Resende AM, Simões DA, Morais MA Jr (2005) Isolation by genetic and physiological characteristics of fuel-ethanol fermentative Saccharomyces cerevisiae strain with potential for genetic manipulation. J Ind Microbiol Biotechnol 32(10):481-486

22. Huang R, Su R, Qi W, He Z (2011) Bioconversion of lignocellulose into bioethanol: process intensification and mechanism research. BioEnergy Res 4:225-245. doi:10.1007/s12155-011-9125-7

23. Kelbert M, Romaní A, Coelho E, Pereira FB, Teixeira JA, Domingues L (2015) Lignocellulosic bioethanol production with revalorization of low-cost agroindustrial by-products as nutritional supplements. Ind Crop Prod 64:16-24. doi:10.1016/j.indcrop. 2014.10.056

24. Romaní A, Ruiz HA, Pereira FB, Teixeira JA, Domingues L (2014) Integrated approach for effective bioethanol production using whole slurry from autohydrolyzed Eucalyptus globulus wood at high-solid loadings. Fuel 135:482-491. doi:10.1016/j.fuel.2014. 06.061

25. Romaní A, Garrote G, Parajó JC (2012) Bioethanol production from autohydrolyzed Eucalyptus globulus by Simultaneous saccharification and fermentation operating at high solid loading. Fuel 94:305-312. doi:10.1016/j.fuel.2011.12.013

26. Ghose TS (1987) Measurement of cellulase activities. Pure Appl Chem 59:257-268. doi:10.1351/pac198759020257

27. Paquot M, Thonart $P$ (1982) Hydrolyse enzymatique de la cellulose régénérée. Holzforschung 36:177-181. doi:10.1515/hfsg.1982.36. 4.177

28. Bailey MJ, Biely P, Poutanen K (1992) Interlaboratory testing of methods for assay of xylanase activity. J Biotechnol 23:257-272. doi:10.1016/0168-1656(92)90074-J

29. Silva-Fernandes T, Duarte LC, Carvalheiro F, Loureiro-Dias MC, Fonseca C, Gírio F (2015) Hydrothermal pretreatment of several lignocellulosic mixtures containing wheat straw and two hardwood residues available in Southern Europe. Bioresour Technol 183:213220. doi:10.1016/j.biortech.2015.01.059

30. Lin CZK, Koutinas AA, Stamatelatou K, Mubofu EB, Matharu AS, Kopsahelis N, Pfaltzgraff Clark JH, Papanikolaou S, Kwan TH, Luque R (2014) Current and future trends in food waste valorization for the production of chemicals, materials and fuels: a global perspective. Biofuels Bioprod Biorefin 8(5):686-715. doi:10.1002/ bbb. 1506

31. Zhu JQ, Qin L, Li W-C, Zhang J, Bao J, Huang Y-D, Li B-Z, Yuan Y-J (2015) Simultaneous saccharification and co-fermentation of dry diluted acid pretreated corn sotver at high dry matter loading: overcoming inhibitors by non-tolerant yeast. Bioresour Technol 198:39-46. doi:10.1016/j.biortech.2015.08.140

32. Van Uden N (1985) Temperature profiles of yeast. Adv Microb Physiol 25:195-251. doi:10.1016/S0065-2911(08)60293-3

33. Ramos MT, Madeira-Lopes A (1990) Effects of acetic acid on the temperature profile of ethanol tolerance in Saccharomyces cerevisiae. Biotechnol Lett 12(3):229-234

34. Mutturi S, Lidén G (2013) Effect of temperature on simultaneous saccharification and fermentation of pretreated spruce and arundo. Ind Eng Chem Res 52(3):1244-1251. doi:10.1021/ie302851w

35. Lu Y, Cheng Y-F, He X-P, Guo X-N, Zhang B-R (2012) Improvement of robustness and ethanol production of ethanologenic Saccharomyces cerevisiae under co-stress of heat and inhibitors. J Ind Microbiol Biotechnol 39:73-80. doi:10. 1007/s10295-011-1001-0

36. Wallace-Salinas V, Gorwa-Grauslund MF (2013) Adaptive evolution of an industrial strain of Saccharomyces cerevisiae for combined tolerance to inhibitors and temperature. Biotechnol Biofuels 6:151. doi:10.1186/1754-6834-6-151

37. Pereira FB, Teixeira MC, Mira NP, Sá-Correia I, Domingues L (2014) Genome-wide screening of Saccharomyces cerevisiae genes required to foster tolerance towards industrial wheat straw hydrolysate. J Ind Microbiol Biotechnol 41:1753-1761. doi:10.1007/ s10295-014-1519-Z

38. Favaro L, Basaglia M, Trento A, Van Rensburg E, García-Aparicio M, Van Zyl WH, Casella S (2013) Exploring grape marc as trove for new thermotolerant and inhibitor-tolerant Saccharomyces cerevisiae strains for second-generation bioethanol production. Biotechnol Biofuels 6(1):168. doi:10.1186/1754-6834-6-168

39. Pereira FB, Guimarães PMR, Gomes DG, Mira NP, Teixeira MC, Sá-Correia I, Domingues L (2011) Identification of candidate genes for yeast engineering to improve bioethanol production in very high gravity and lignocellulosic biomass industrial fermentations. Biotechnol Biofuels 57. doi:10.1186/1754-6834-4-57.

40. Sasikumar E, Viruthagiri T (2008) Optimization of process conditions using response surface methodology (RSM) for ethanol production from pretreated sugarcane bagasse: kinetics and modeling. Bioenergy Res 1(3):239-247. doi:10.1007/s12155-008-9018-6

41. Wallace-Salinas V (2014) Improving stress tolerance in industrial Saccharomyces cerevisiae strains for ethanol production from lignocellulosic biomass doctoral. Thesis, Lund University

42. Mensonides FI, Schuurmans JM, Teixeira de Mattos MJ, Hellingwerf KJ, Brul S (2002) The metabolic response of Saccharomyces cerevisiae to continuous heat stress. Mol Biol Rep 29(1-2):103-106

43. Liu Z-H, Qin L, Zhu J-Q, Li B-Z, Yuan Y-J (2014) Simultaneous saccharification and fermentation of steam-exploded corn stover at high glucan loading and high temperature. Biotechnol Biofuels 7(1):167. doi:10.1186/s13068-014-0167-x

44. Zhu JY, Chandra MS, Gu F, Gleisner R, Reiner R, Sessions J, Marrs G, Gao J, Anderson D (2015) Using sulphite chemistry for robust bioconversion of Douglas-fir forest residue to bioethanol at high titer and lignosulfonate: a pilot-scale evaluation. Bioresour Technol 179:390-397. doi:10.1016/j.biortech.2014.12.052 